\title{
Editorial \\ Performance and Safety Enhancement Strategies in Vehicle Dynamics and Ground Contact
}

\author{
Flavio Farroni *(D), Andrea Genovese (D) and Aleksandr Sakhnevych (D) \\ Department of Industrial Engineering, University of Naples Federico II, 80131 Naples, Italy; \\ andrea.genovese2@unina.it (A.G.); ale.sak@unina.it (A.S.) \\ * Correspondence: flavio.farroni@unina.it
}

check for updates

Citation: Farroni, F.; Genovese, A.; Sakhnevych, A. Performance and Safety Enhancement Strategies in Vehicle Dynamics and Ground Contact. Appl. Sci. 2022, 12, 2034. https://doi.org/10.3390/ app12042034

Received: 7 February 2022 Accepted: 11 February 2022 Published: 16 February 2022

Publisher's Note: MDPI stays neutral with regard to jurisdictional claims in published maps and institutional affiliations.

Copyright: (C) 2022 by the authors. Licensee MDPI, Basel, Switzerland. This article is an open access article distributed under the terms and conditions of the Creative Commons Attribution (CC BY) license (https:// creativecommons.org/licenses/by/ $4.0 /)$.
Recent trends in vehicle engineering prove the great effort that scientists and industries have made in seeking solutions to enhance both the performance and the safety of vehicular systems. Physical models concerning vehicle-ground interaction, control strategies for the vehicle and its subsystems, and new technologies are developing all over the world for this purpose. The published Special Issue contributed to the study of modern vehicle dynamics, attracting recent experimental and in-simulation advances that are the basis for the current technological growth and for future mobility. Such areas involve research, studies, and projects coming from both vehicle dynamics and contact mechanics, with the perspective to embrace activities aiming to enhance vehicle performance in terms of handling, comfort, and adherence and to examine safety optimization also in the emerging contexts of smart, connected, and autonomous driving.

The accepted scientific contributions covered topics concerning new results and studies in the following areas related to the interaction of vehicle dynamics and the ground:

- Physical models concerning tire-road and vehicle-ground interaction: In particular, Ref. [1] refers to new developments in airless (or non-pneumatic) tires, representing a significant perspective in the future evolution of such components. Regarding tires, Ref. [2] proposes strategies to optimize tread wear and minimize the dispersion of rubber particles, properly acting on wheel and suspension setup. Moreover, Refs. [3,4] focus on materials characterization and local contact phenomena, analyzing, respectively, innovative polynomial formulations for the reproduction of viscoelastic compounds' behaviors and the adhesive effects of dimpled textures in contact with flat surfaces. Finally, Ref. [5] proposes artificial neural networks to identify the parameters of Pacejka's Magic Formula tire models, widely adopted in the context of automotive simulations;

- Experimental activities aimed at the investigation and the comprehension of interaction phenomena: Among the published papers, some developed an approach based on the macroscale effects, analyzing the whole vehicle data as proposed in Ref. [6], mainly centered on ride analysis on wavy profiles; In Ref. [7], accounting for suspension sensitivity to road roughness, longitudinal speed, and vehicle segment; and in Ref. [8], switching to the effects on the directional capabilities. Some other authors worked on the microscale, accounting for indentation, friction, and contact mechanics at the ground, as investigated in Ref. [9], relating to gravel surfaces and noise, and in Ref. [4], focusing also on aspects related to adhesive local contact phenomena;

- Control strategies focused on vehicle performance enhancement, in terms of handling/grip, comfort, and safety: In Ref. [10], a safety control strategy is proposed, acting on the steering system and differential, useful for performing emergency maneuvers for obstacle avoidance; In Ref. [11], a central predictive control system is proposed, acting on a non-linear, model-based predictive algorithm; and in Ref. [12], the onboard implementation of friction estimation, in autonomous driving and vehicle following applications, is illustrated. The authors of one of the submitted papers also 
focused on traffic contexts, in particular reporting a case study involving Duisburg Ring environment [13];

- Innovative technologies to improve the safety and performance of the vehicle and its subsystems, such as adopting active/semiactive suspension in in-wheel architectures, enhancing the roadholding [14] and stability-oriented steering systems in articulated vehicle applications [15];

- Identification of vehicle and tire/wheel model parameters and state with innovative methodologies and algorithms, based on machine learning techniques, as described in Ref. [5];

- Implementation of real-time software, logics, and models in onboard architectures [13] with a main target involving applications oriented towards autonomous driving and connected mobility scenarios;

- Studies and analyses oriented toward the correlation among the factors affecting vehicle consumptions, such as in powertrain architectures in electric mobility described in Ref. [16], or performance and stability, with the target to propose strategies for the minimization of undesired phenomena, as proposed by the authors of the article [2], who focused on tire tread wear;

- Application use cases in scenarios not only concerning car and conventional fourwheeled vehicles or common asphalt roads. The published papers represent advances in vehicle dynamics also involving off-road vehicles, as analyzed in Ref. [9], heavy articulated vehicles [15], or motorcycles, for which [17] proposed a study on their stability, developing an innovative approach based on the so-called screw axis instead of the usual phase plane.

Author Contributions: Conceptualization, F.F.; writing—original draft preparation, F.F.; writingreview and editing, A.S. and A.G.; All authors have read and agreed to the published version of the manuscript.

Funding: This research received no external funding.

Institutional Review Board Statement: Not applicable.

Data Availability Statement: Not applicable.

Conflicts of Interest: The authors declare no conflict of interest.

\section{References}

1. Genovese, A.; Garofano, D.; Sakhnevych, A.; Timpone, F.; Farroni, F. Static and Dynamic Analysis of Non-Pneumatic Tires Based on Experimental and Numerical Methods. Appl. Sci. 2021, 11, 11232. [CrossRef]

2. Papaioannou, G.; Jerrelind, J.; Drugge, L. Multi-Objective Optimisation of Tyre and Suspension Parameters during Cornering for Different Road Roughness Profiles. Appl. Sci. 2021, 11, 5934. [CrossRef]

3. Tassara, M.; Grigoriadis, K.; Mavros, G. Empirical Models for the Viscoelastic Complex Modulus with an Application to Rubber Friction. Appl. Sci. 2021, 11, 4831. [CrossRef]

4. Papangelo, A. On the Effect of a Rate-Dependent Work of Adhesion in the Detachment of a Dimpled Surface. Appl. Sci. 2021, 11, 3107. [CrossRef]

5. Olazagoitia, J.; Perez, J.; Badea, F. Identification of Tire Model Parameters with Artificial Neural Networks. Appl. Sci. 2020, 10, 9110. [CrossRef]

6. Wedig, W. Speed Oscillations of a Vehicle Rolling on a Wavy Road. Appl. Sci. 2021, 11, 10431. [CrossRef]

7. Lukoševičius, V.; Makaras, R.; Rutka, A.; Keršys, R.; Dargužis, A.; Skvireckas, R. Investigation of Vehicle Stability with Consideration of Suspension Performance. Appl. Sci. 2021, 11, 9778. [CrossRef]

8. Lukoševičius, V.; Makaras, R.; Dargužis, A. Assessment of Tire Features for Modeling Vehicle Stability in Case of Vertical Road Excitation. Appl. Sci. 2021, 11, 6608. [CrossRef]

9. Žuraulis, V.; Sivilevičius, H.; Šabanovič, E.; Ivanov, V.; Skrickij, V. Variability of Gravel Pavement Roughness: An Analysis of the Impact on Vehicle Dynamic Response and Driving Comfort. Appl. Sci. 2021, 11, 7582. [CrossRef]

10. Lin, Y.; Chen, B. Handling Enhancement of Autonomous Emergency Steering for Reduced Road Friction Using Steering and Differential Braking. Appl. Sci. 2021, 11, 4891. [CrossRef]

11. Sieberg, P.; Schramm, D. Central Non-Linear Model-Based Predictive Vehicle Dynamics Control. Appl. Sci. 2021, 11, 4687. [CrossRef]

12. Santini, S.; Albarella, N.; Arricale, V.; Brancati, R.; Sakhnevych, A. On-Board Road Friction Estimation Technique for Autonomous Driving Vehicle-Following Maneuvers. Appl. Sci. 2021, 11, 2197. [CrossRef] 
13. Ma, X.; Hu, X.; Weber, T.; Schramm, D. Traffic Simulation of Future Intelligent Vehicles in Duisburg City Inner Ring. Appl. Sci. 2021, 11, 29. [CrossRef]

14. Woo, S.; Shin, D. A Double Sky-Hook Algorithm for Improving Road-Holding Property in Semi-Active Suspension Systems for Application to In-Wheel Motor. Appl. Sci. 2021, 11, 8912. [CrossRef]

15. Lei, T.; Wang, J.; Yao, Z. Modelling and Stability Analysis of Articulated Vehicles. Appl. Sci. 2021, 11, 3663. [CrossRef]

16. Yildiz, A.; Özel, M. A Comparative Study of Energy Consumption and Recovery of Autonomous Fuel-Cell Hydrogen-Electric Vehicles Using Different Powertrains Based on Regenerative Braking and Electronic Stability Control System. Appl. Sci. 2021, 11, 2515. [CrossRef]

17. Bova, M.; Massaro, M. A Screw-Axis Approach to the Stability of Two-Wheeled Vehicles. Appl. Sci. 2021, 11, 7393. [CrossRef] 